\title{
THE RELATIONSHIP BETWEEN URBAN LEAF AREA AND HOUSEHOLD ENERGY USAGE IN TERRE HAUTE, INDIANA, U.S.
}

\author{
by Ryan R. Jensen', James R. Boulton ${ }^{2}$, and Bruce T. Harper ${ }^{3}$
}

\begin{abstract}
The accrual of urban forest amenities and the estimation of these benefits is an essential step in the process of preserving and expanding urban forest resources. The purpose of this paper is to demonstrate that these benefits, specifically decreased cooling costs, can be effectively estimated using a mixed methodological approach that combines remotes sensing technologies with standard statistical analysis. This study tests the relationship between urban forest leaf area index (LAI) and household energy usage in summer 2001 in a mid-sized city. Results indicate an inverse relationship between LAI and energy usage, signifying that as LAI increases, energy usage decreases. This study could be used by urban planners and others to promote urban forests, justify urban forest projects, and assess the outcomes current policy.

Key Words. Urban forest; leaf area index; remote sensing; household energy usage.
\end{abstract}

Human environmental impacts are becoming increasingly severe. This is especially true in urban environments where humans fragment the landscape and degrade natural resources, such as urban forests (trees and associated vegetation) (Nowak et al. 2001). As a result of observed environmental degradation and the dynamic interaction between social and natural systems in urban environments, urban forestry has been increasingly recognized as a viable policy vehicle for improving the overall quality of life in urban regions, promoting economic well-being, and mitigating the environmental impact of urbanization (e.g., Nowak et al. 2001; Gatrell and Jensen 2003). Indeed, a review of the urban planning literature clearly demonstrates that an environmental ethos serves to unify the combined discourses on smart growth, slow grow, farmland preservation, and a variety of other grassroots urban politics (Calavita 1992, 1997; Calavita and Caves 1994; Freilich 1999; Weitz 1999).

Given the tangible and intangible benefits of urban forests, urban residents and policy makers will no doubt continue to design, implement, and assess urban forestry programs. To date though, program assessment has been uneven. The purpose of this study is to demonstrate one possible assessment framework that might be useful to investigate the overall costs and benefits of urban forests. In this study, the relationship between summer household energy usage and urban canopy cover in a mid-sized city, Terre Haute, Indiana, U.S., is explored. It is different from other urban forest studies because it quantitatively estimated Terre Haute's urban forest in terms of leaf area index (LAI) that was then correlated with household energy usage. This kind of study may be useful for planners, landscape architects, and governmental officials to demonstrate the economic importance of urban forests and enable them to more effectively justify urban forest management.

\section{METHODS}

\section{Study Area}

Terre Haute (population 69,614; U.S. Census 2000) is located in Vigo County along the banks of the Wabash River in west-central Indiana (Figure 1). Terre Haute actively maintains its tree canopy through a tree ordinance that governs tree removal and planting. The ordinance is governed by a rotating tree board and implemented by a full-time city forester.

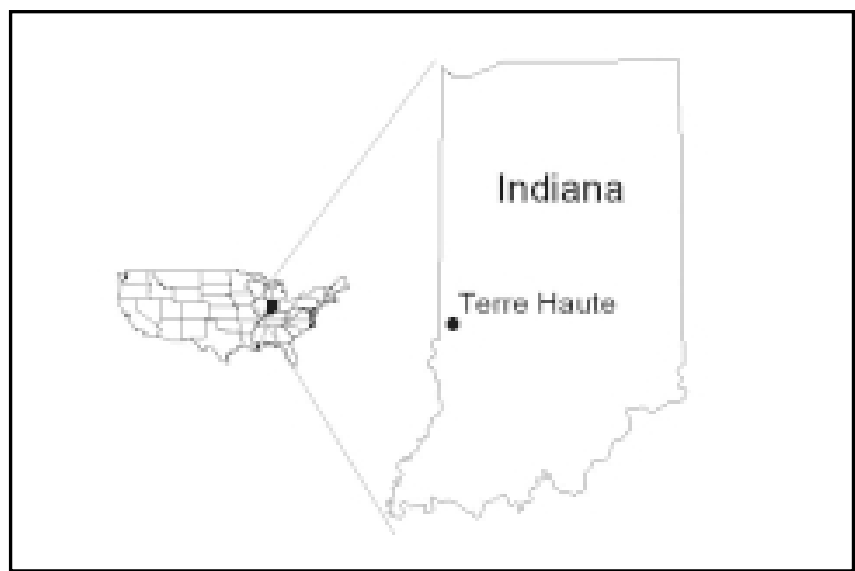

Figure 1. Map of Terre Haute, Indiana, U.S.

\section{LAI Field Measurements}

Leaf area index (LAI), $\mathrm{m}^{2}$ of leaf per $\mathrm{m}^{2}$ of ground, has been identified as one of the most important biophysical variables for landscape to regional-scale research (Pierce and Running 1998; Lymburner et al. 2000). Traditional field 
measurement of LAI usually requires destructive harvesting of leaves within a vertical quadrat through the entire canopy or through leaf litterfall collection techniques. These direct methods are similar in that they require many replicates to account for spatial variability in the canopy and are time intensive (Green et al. 1997). However, these LAI measurements are accurate at a very specific geographic location, are unambiguous, and are well understood by ecologists.

Recently, new unobtrusive field methods have been developed to estimate LAI. One of these methods is based on gap-fraction analysis. Gap-fraction theory states that for whole canopies, the decrease in light intensity (light attenuation) with increasing depth can be described by the equation

$$
I L / I L=e^{-k L A I(L)}
$$

where IL/IO is the fraction of incident light at the top of the canopy (IO) reaching depth $L$ in the canopy, $\operatorname{LAI}(L)$ is the cumulative LAI from the top of the canopy to point $L, k$ is a stand or species specific constant, and $e$ is the base of natural logarithms (Larcher 1975; Aber and Melillo 1991). Different types of vegetation have different $k$ values, causing different rates of light attenuation for the same amount of leaf area. The principal factor causing this is differences in the angle at which the leaves are displayed (Larcher 1975).

LAI measured using in situ gap-fraction analysis assumes that leaf area can be calculated from canopy transmittance of light (the fraction of direct solar energy that penetrates the canopy). Gap-fraction techniques have been used to study LAI in many different forest studies (e.g., Pierce and Running 1988; Chason et al. 1991; Ellsworth and Reich 1993; Nel and Wessman 1993; Green et al. 1997).

LAI was measured using the gap-fraction method with a Decagon AccuPar Ceptometer ${ }^{\mathrm{TM}}$ in 118 random locations throughout the study area. The ceptometer consists of a linear array of 80 adjacent $1 \mathrm{~cm}^{2}$ photosynthetically active radiation (PAR) sensors along a bar. Coordinates were determined for each point and were programmed into a handheld global positioning system receiver. At each sampling point, 16 below-canopy PAR measurements were collected, one in each cardinal direction at each corner of a $20 \mathrm{~m}$ quadrat with the ceptometer held at waist height of the observer, approximately $1 \mathrm{~m}$ above the ground. The ceptometer calculated an arithmetic mean for each point based on the 16 PAR samples. The calculated LAI value for the point was noted in a field log along with operator notes regarding the sampling point.

\section{Satellite Imagery}

A sample of 118 LAI points is insufficient to adequately describe LAI in all of Terre Haute. Therefore, satellite remote sensing data were obtained that radiometrically measured the entire city. The field LAI measurements were then used to develop models to convert the satellite data to LAI. Data from the Advanced Spaceborne Thermal Emission and Reflection Radiometer (ASTER) sensor were used to provide complete coverage of the study area. ASTER is a relatively new space-borne sensor that is similar in spectral resolution to Landsat Thematic Mapper data, but it is collected at a spatial resolution of $15 \mathrm{~m}$ versus the $30 \mathrm{~m}$ resolution of the thematic mapper. An ASTER image of the study area acquired in July 2001 was used for this study. The image was geometrically corrected using a United States Geological Survey Digital Raster Graphic image.

ASTER data are collected in several wavelengths, often referred to as bands. This study employed bands 1,2 , and 3 measuring the green, red, and near-infrared segments of the electromagnetic spectrum $(520-600 \mathrm{~nm}, 630-690 \mathrm{~nm}$, and $790-860 \mathrm{~nm}$, respectively). These wavelengths are frequently used in vegetation studies because of their correlation to the quantity and health of green vegetation (Jensen 2000a).

Like most urban/suburban areas, land cover in Terre Haute consists of a wide variety of vegetated and nonvegetated areas. Vegetated areas include trees, shrubs, grasses, and agricultural fields growing different varieties of corn and soybeans. Nonvegetated areas include buildings, streets, parking lots, ponds, lakes, and the Wabash River. The randomly selected sampling sites represented all land cover types.

\section{LAI Model}

Reflectance values were extracted from each spectral band at each of the 118 LAI sampling points. These values were then placed into regression analyses and an artificial neural network to determine the most accurate method to estimate LAI. Remote sensing models often employ statistical methods such as linear regression to extrapolate point measurements to the landscape scale or greater. Recently, new techniques, such as artificial neural network models, have been developed that are often more accurate than traditional statistical models (Jensen 2000b).

The neural network model yielded the smallest error between the field-measured LAI values and the LAI values derived from the model. This network model was used to estimate LAI at locations in the study area where field measurements had not been taken.

\section{Household Energy}

Privacy laws complicated the acquisition of household electrical usage data because the local utility company, Cinergy PSI, could not release customer billing information without customer approval. Therefore, a list of random addresses was provided to Cinergy and they returned a listing of kilowatt-hours by billing period for an address on the same city block as the pseudo-address and listed as though it were for the address. For example, if an address such as "550 North 13th Street" was given to Cinergy, they would return the energy information from a residence on the 500 north block on 13th street.

This study examined electrical usage during the cooling season, which was defined as April 15 to September 15. 
Electric meters were read at individual residences once each month, but not all the meters were read on the same day. Some of the residences reported had months where the service was disconnected for a period of time; others seemed to have one or more skipped readings. To remedy this, all readings were normalized to a kilowatt hours per day value.

The pseudo-addresses were geocoded to a GIS map using the USGS DRG maps used earlier to geo-reference the satellite image. In some cases, the USGS map did not show a street at the site of the pseudo-address. For those cases, the Internet mapping service MapQuest was used to locate the address, and its location on the USGS map was estimated as best as possible.

To offset the inability to map the exact location of the residences in the Cinergy database, the satellite data were averaged. In the averaging process, each pixel was assigned a value equal to the statistical mean of the nearest group of pixels using a three by three pixel block average. For each pseudo-address location, reflectance information was averaged and extracted from the ASTER image in the three bands. Then, using the artificial neural network created previously, LAI values for the pseudo-addresses were estimated.

\section{RESULTS}

Using regression analysis, estimated LAI values were compared to the $\mathrm{kw}$-hr per day usage information obtained from Cinergy PSI. The resulting coefficient of correlation was very low $(r=-0.10 ; \mathrm{kw}-\mathrm{hr}$ per day $=-4.17368 * \mathrm{LAI}+$ 44.8), indicating that the presence or absence of trees has little effect on electrical usage by residential households in Terre Haute. Although the correlation was not very significant $(p=0.151)$, the direction of the correlation is encouraging because it indicated an inverse relationship between LAI and energy usage; that is, as the amount of nearby overhead canopy increases there was a decrease in electrical usage. In fact, the regression equation states that for every one-unit increase in LAI, $\mathrm{kw}$-hr per day, usage decreases by 4.17368 . Using an average of US $\$ 0.075 / \mathrm{kw}-\mathrm{hr}$, this decrease equates to a potential savings of US $\$ 0.31$ per day, or around US $\$ 30$ for the entire cooling period.

The data plot revealed several features (Figure 2). First, there is a large cluster of noncorrelated points at the low end of both electricity consumption and LAI. For this study, no attempt was made to group houses by any factors beyond the density of LAI in the immediate vicinity of the house. Second, an examination of the outliers indicates that the highest electricity usage occurred in residences with low LAI values and the residences with the densest canopies were also low consumers of electricity. Moreover, no single occurrence of "high" usage could be isolated in areas of dense overhead canopy.

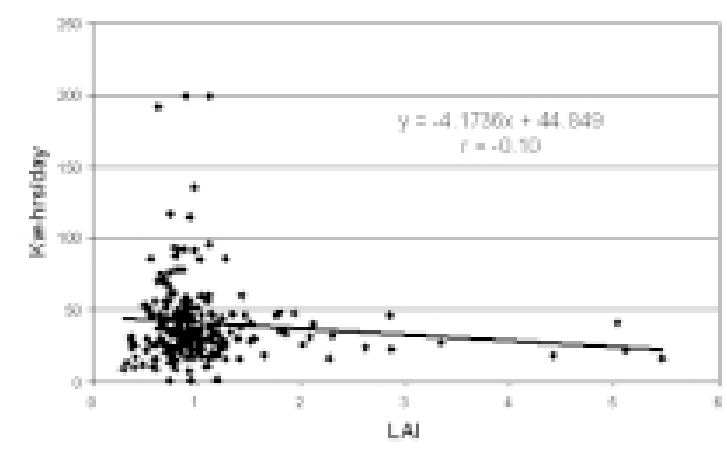

Figure 2. Scatter plot of $\mathrm{kw}$-hr per day and estimated leaf area index.

\section{DISCUSSION}

Summertime electrical usage is a very complex function influenced by many factors such as age of the home, size of the home, amount of insulation, number of residents in the home, the size and type of air-conditioning equipment used, thermostat temperature, precautions taken during the day to exclude sunshine from the interior of the home, and the presence or absence of nearby overhead leafy canopy. The pseudo-addresses used in this study further complicated the relationship between household energy usage and LAI. However, this study indicated that the presence of a leafy overhead canopy might have contributed to lower electricity consumption during the summer of 2001 even though it was not a significant contribution. Studies like this one could serve to promote the direct economic benefits of urban forests to the general public, and future studies could focus on methods to control for the other factors listed above. Likewise, studies like this could be used to assess the tangible costs and benefits associated with urban forestry programs.

\section{LITERATURE CITED}

Aber, J.D., and J.M. Melillo. 1991. Terrestrial Ecosystems. Saunders College Publishing, Chicago, IL.

Calavita, N. 1992. Growth machines and ballot box planning. The San Diego case. J. Urban Affairs 14(1):1-24. 1997. Vale of tiers. Planning 63(3):18-21.

Calavita, N., and R. Caves. 1994. Planners' attitudes toward growth: A comparative case study. J. Am. Planning Assoc. 60:483-500.

Chason, J.W., D.D. Baldocchi, and M.A. Huston. 1991. A comparison of direct and indirect methods for estimating forest canopy leaf area. Agric. For. Meteorol. 57:107-128.

Ellsworth, D.S., and P.B. Reich. 1993. Canopy structure and vertical patterns of photosynthesis and related leaf traits in a deciduous forest. Oceologia 96:169-178. 
Freilich, R. 1999. From Sprawl to Growth: Successful Legal, Planning, and Environmental Systems. American Bar Association, Chicago. IL.

Gatrell, J.G., and R.R. Jensen. 2003. Growth through greening: developing and assessing alternative economic development programs." Appl. Geog. 22:331-350.

Green, E.P., P.J. Mumby, A.J. Edwards, C.D. Clark, and A.C. Ellis. 1997. Estimating leaf area index of mangroves from satellite data. Aqua. Bot. 58:11-19.

Jensen, J.R. 2000a. Remote Sensing of the Environment: An Earth Resources Perspective. Prentice Hall, Englewood Cliffs, NJ.

Jensen, R.R. 2000b. Measurement, Comparison, and Use of Remotely Derived Leaf Area Index Predictors. Thesis, University of Florida. 133 pp.

Larcher, W. 1975. Physiological Plant Ecology. SpringerVerlag, New York, NY.

Lymburner, L, P.J. Beggs, and C.R. Jacobson. 2000.

Estimation of canopy-average surface-specific leaf area using Landsat TM data. Photogramm. Eng. Remote Sens. 66:183-191.

Nel, E.M., and C.A. Wessman. 1993. Canopy transmittance models for estimating forest leaf area index. Can. J. For. Resourc. 23:2579-2586.
Nowak, D.J., M.H. Noble, S.M. Sisinni, and J.F. Dwyer. 2001. Assessing the US urban forest resource. J. For. 99:37-42.

Pierce, L.L., and S.W. Running. 1988. Rapid estimation of coniferous forest leaf area index using a portable integrating radiometer. Ecology 69:1762-1767.

Weitz, J. 1999. Sprawl Busting: State Programs to Guide Growth. APA Planners Press, Chicago, IL.

Acknowledgments. This project was funded through a Community and Urban Forestry Grant provided with United States Forest Service pass-through funds by the Indiana Department of Natural Resources, Urban Forestry Division.

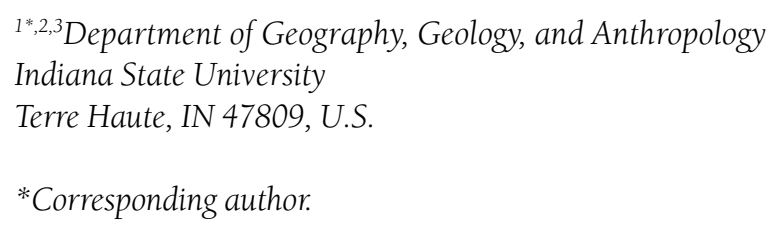

*Corresponding author. 
Résumé. Le décompte des agréments que procurent la forêt urbaine ainsi que l'estimation de ces bénéfices est une étape essentielle dans le processus de préservation et d'expansion des ressources forestières urbaines. Le but de cet article est de démontrer que ces bénéfices, plus spécifiquement ceux liés aux coûts décroissant de climatisation, peuvent être effectivement estimés en utilisant une approche méthodologique mixte qui combine des technologies de mesurage par des senseurs avec des analyses statistiques standards. Cette étude teste la relation entre l'index de la surface foliaire de la forêt urbaine et les besoins énergétiques d'une maison durant l'été 2001, et ce dans une ville de taille moyenne. Les résultats indiquent une relation inverse entre la surface foliaire de la forêt urbaine et les besoins énergétiques, ce qui signifie qu'avec un accroissement de l'index de surface foliaire il y a une diminution des besoins énergétiques. Cette étude peut être utilisée par les planificateurs urbains et autres professionnels pour promouvoir les forêts urbaines, justifiant ainsi les projets de forêts urbaines et l'évaluation de leurs bénéfices attendus dans les politiques courantes.

Zusammenfassung. Der Anspruch an die Annehmlichkeiten städtischer Forstanlagen und die Schätzung dieser Vorteile ist ein wichtiger Schritt im Prozeß um die Erhaltung und Expansion städtischer Waldresourcen. Die Absicht dieser Studie liegt darin zu demonstrieren, dass diese Vorteile, besonders die reduzierten Kühlungskosten, effektiv geschätzt werden können, indem ein methodischer Ansatz verwendet wird, der Wahrnehmungstechnologien nicht statistischen Standartanalysen verbindet.. Diese Studie testet die Beziehung zwischen Blattflächenindex und dem Energiehaushalt im Sommer 2001 in einer mittelgroßen Stadt. Die Ergebnisse zeigen eine inverse Beziehung zwischen Blattflächenindex und Energieverbrauch, bzw. dass der Blattflächeninex steigt und der Energieverbrauch sinkt. Diese Studie könnte von Städteplannern und anderen involvierten Personen benutzt werden, urbane Forstanlagen entsprechend auszurichten.

Resumen. La determinación de los atractivos del bosque urbano y la estimación de estos beneficios son un paso importante en los procesos de preservación y expansión de los recursos forestales urbanos. El propósito de este reporte es demostrar que estos beneficios, específicamente la disminución de los costos de enfriamiento de aire acondicionado, pueden ser efectivamente estimados usando una aproximación metodológica mixta que combina las tecnologías de sensores remotos con el análisis estadístico estándar. Este estudio prueba la relación entre el índice de área foliar (IAF) del bosque urbano y el uso de energía doméstica en el verano de 2001 en ciudades medias. Los resultados indican una relación inversa entre IAF y el uso de energía, significando esto que a medida que IAF incrementa, el uso de la energía disminuye. Este estudio podría ser usado por los planificadores y otros especialistas para promover los bosques urbanos. 